\title{
Effects of changes in the intakes of protein and non-protein energy on whole-body protein turnover in growing pigs
}

\author{
By P. J. REEDS, M. F. FULLER, A. CADENHEAD, G. E. LOBLEY \\ AND J. D. MCDONALD \\ Rowett Research Institute, Bucksburn, Aberdeen AB2 9SB
}

(Received 30 June 1980 - Accepted 12 December 1980)

\begin{abstract}
1. The relationships between the intakes of protein and of non-protein energy (NPE), nitrogen retention and body protein synthesis have been studied in female pigs weighing 30 and $35 \mathrm{~kg}$.

2. Four animals were assigned to three regimens and given a conventional (basal) diet supplemented with fat, carbohydrate or protein. After 1 week, measurements of $\mathbf{N}$ excretion in urine and faeces ( $7 \mathrm{~d}$ collection) and gaseous exchange (3-4 d) were made. At the end of the balance period a solution of [1-14 C]leucine was infused at a constant rate. Body protein synthesis was then calculated as the difference between the apparent irreversible loss of blood leucine and the loss of ${ }^{14} \mathrm{C}$ in expired air.
\end{abstract}

The animals were then offered the basal diet without supplement for $10 \mathrm{~d}$ and the measurements of $\mathrm{N}$ retention, energy retention and protein synthesis were repeated.

3. The intakes of metabolizable energy (ME; $\mathrm{MJ} / \mathrm{kg}$ body-weight (W) ${ }^{0.75}$ per d) were 1.75 for fat, 1.58 for carbohydrate, 1.25 for protein and $1 \cdot 18$ for the basal diet; corresponding intakes of apparently digestible $N$ (ADN; $\mathrm{g} \mathrm{N} / \mathrm{kg}^{0.35}$ per d) were $2 \cdot 30,2 \cdot 31,4 \cdot 35$ and $2 \cdot 17$. Daily $\mathbf{N}$ retention, which during the period of basal feeding was $13.6 \mathrm{~g}$ was increased by between 3.4 and $7.2 \mathrm{~g}$ by the supplements. Daily fat deposition was also increased in the animals that received the diets supplemented with carbohydrate and fat.

4. The rate of leucine catabolism was significantly reduced in the animals receiving the diets that were supplemented with NPE and increased by the addition of protein to the diet.

5. When based on the specific radioactivity of blood leucine both the synthesis and breakdown of body protein (per unit metabolic body-weight) were increased by $30 \%$ in the animals receiving the high-protein diet but the increases in protein synthesis associated with the addition of carbohydrate $(+14 \%)$ and fat $(+12 \%)$ were much less marked. Consideration of these results together with previous observations (Reeds et al. 1980) suggested that body protein synthesis $(\mathrm{g} \mathrm{N} / \mathrm{d}$ ) increased by 0.88 for each $\mathrm{g}$ increase in daily $\mathrm{ADN}$ and by 0.93 for each MJ increase in daily ME intake.

6. Comparison of the results obtained with the animals given high-carbohydrate diets and those given high-protein diets suggested an increase in heat production of $14 \mathrm{KJ} / \mathrm{g}$ of additional fat deposition. A similar comparison of animals receiving the high-protein and basal diets suggested a heat increment of $23.5 \mathrm{KJ} / \mathrm{g}$ additional protein deposition. The changes in heat production and protein synthesis in the animals given the protein supplement were compatible with a heat increment of $5.3 \mathrm{KJ} / \mathrm{g}$ additional protein synthesized. Because of the large proportion of heat production associated with the deposition of fat this could not be confirmed with either of the other supplements, but it is possible that the energy cost of protein accretion varies with the relative proportions of protein and NPE in the diet.

At a fixed intake of dietary protein the rate of nitrogen retention is dependant on the amount of non-protein energy (NPE) in the diet. Carbohydrate and fat are equally effective in promoting $\mathbf{N}$ retention (Forbes et al. 1939; Munro, 1964; Nakano \& Ashida, 1975). The underlying mechanisms which are responsible for the change in $\mathbf{N}$ retention are not well understood but must involve changes in the relative rates of synthesis and breakdown of body protein. Changes in both protein synthesis and breakdown (Munro et al. 1959; Nakano et al. 1973) as well as changes in hepatic amino acid catabolic enzymes (Nakano \& Ashida, 1969) have been implicated in the control of protein deposition by NPE.

In growing pigs (Reeds et al. 1980) and children (Golden et al. 1977) increases in $N$ retention associated with increases in food intake are accompanied by higher rates of both protein synthesis and protein breakdown in the whole body. This paper reports the results of experiments to discover whether these changes in body protein turnover are the result of separate responses to dietary protein and to NPE, or whether they are invariably associated with alterations of $\mathbf{N}$ retention, howsoever produced. 


\section{METHODS}

Animals and diets

The experiments were carried out with twelve female pigs which were the progeny of Large White boars and Large White $\times$ Landrace sows.

The basal diet consisted largely of cereals (Reeds et al. 1980) and when given at a rate of $90 \mathrm{~g} / \mathrm{kg}$ body-weight (W) ${ }^{0.75}$ per d (groups 30FB, 30CB and 30 PB) supplied approximately $1.2 \mathrm{MJ}$ metabolizable energy (ME) and $2.2 \mathrm{~g}$ of apparently-digestible $\mathrm{N}(\mathrm{ADN}) / \mathrm{kg} \mathrm{W}^{0.75}$ per d. Two diets of a higher energy: protein value were prepared by adding to $1 \mathrm{~kg}$ basal diet: $180 \mathrm{~g}$ lard (fat diet, group 30F), $407 \mathrm{~g}$ maize starch (one animal) or $264 \mathrm{~g}$ sucrose (three animals) (carbohydrate diet, group 30C). Additional vitamins, minerals and cellulose were also added.

A third diet (protein diet, group 30P) was also prepared by adding to $1 \mathrm{~kg}$ basal diet: $380 \mathrm{~g}$ soya-bean protein isolate (Promine D; Central Soya Co., Chicago, USA). The addition of the protein supplement had a negligible effect on the amino acid composition of the diet.

The diets were offered to the pigs once hourly at daily rates $\left(\mathrm{g} / \mathrm{kg} \mathrm{W}^{0.75}\right)$ of 124 (group 30S), 113 (group 30F) and 88 (group 30P), the aim being to achieve intakes of $1.8 \mathrm{MJ} \mathrm{ME}$ and $2.4 \mathrm{ADN} / \mathrm{kg} \mathrm{W}^{0.75}$ per d for groups $30 \mathrm{~F}$ and $30 \mathrm{C}$ and $1.2 \mathrm{MJ}$ ME and $4.3 \mathrm{~g} \mathrm{ADN} / \mathrm{kg} \mathrm{W}^{0.75}$ per $\mathrm{d}$ for group 30P. The intakes of ME and ADN that were attained are shown in Table 1.

\section{Experimental design and procedures}

Two PVC catheters (NT2; Portex Ltd, Hyde, UK) were introduced into the aorta of the pigs when the animals weighed between 17 and $20 \mathrm{~kg}$ (Fuller et al. 1977; Reeds et al. 1980). For $10 \mathrm{~d}$ after the operation the animals were offered the basal diet once hourly at a rate of $90 \mathrm{~g} / \mathrm{kg} \mathrm{W}$ W $^{0.75}$ per d. When the animals weighed $22 \mathrm{~kg}$ they were randomly assigned to one of the three supplemented diets which were offered once hourly thereafter. When the

Table 1. The body-weights ( $\mathrm{kg}$ ), apparent digestibilities of gross energy $(\mathrm{GE})$ and nitrogen, the daily intakes of metabolizable energy (ME) and apparently digested $N(A D N)$ of twelve female pigs offered basal diets $\dagger$ supplemented with fat (group 30F), carbohydrate (group $30 \mathrm{C}$ ) or protein (group 30P) for $14 d$ and of the same pigs subsequently offered the basal diet for $14 d$ (groups 30FB, 30CB and 30PB)

(Mean values \pm 1 SEM)

\begin{tabular}{|c|c|c|c|c|c|c|c|c|c|c|c|}
\hline \multirow{3}{*}{$\begin{array}{l}\text { Dietary } \\
\text { group }\end{array}$} & \multirow[b]{3}{*}{$n$} & & & \multicolumn{4}{|c|}{ Apparent digestibilities } & \multicolumn{4}{|c|}{ Daily intake } \\
\hline & & \multicolumn{2}{|c|}{$\begin{array}{c}\text { Body-wt } \\
\text { (kg) }\end{array}$} & \multicolumn{2}{|c|}{$\begin{array}{c}\mathrm{GE} \\
(\mathrm{MJ} / \mathrm{MJ})\end{array}$} & \multicolumn{2}{|c|}{$\frac{N}{(g N / g N)}$} & \multicolumn{2}{|c|}{$\begin{array}{c}\text { ME } \\
\left(\mathrm{MJ} / \mathrm{kg} \mathrm{W}^{0.75}\right)\end{array}$} & \multicolumn{2}{|c|}{$\begin{array}{c}\text { ADN } \\
\left(\mathrm{g} \mathrm{N} / \mathrm{kg} \mathrm{W}^{0 \cdot 75}\right)\end{array}$} \\
\hline & & Mean & $\mathbf{S E}$ & Mean & SE & Mean & SE & Mean & SE & Mean & SE \\
\hline $\begin{array}{l}30 \mathrm{~F} \\
30 \mathrm{FB}\end{array}$ & $\begin{array}{l}4 \\
4\end{array}$ & $\begin{array}{l}30.8 \\
35.2\end{array}$ & $\begin{array}{l}1.4 \\
1.6\end{array}$ & $\begin{array}{l}0.841 \\
0.849\end{array}$ & $\begin{array}{l}0.021 \\
0.020\end{array}$ & $\begin{array}{l}0.828 \\
0.847\end{array}$ & $\begin{array}{l}0.014 \\
0.016\end{array}$ & $\begin{array}{l}1 \cdot 75 \\
1 \cdot 18\end{array}$ & $\begin{array}{l}0.05 \\
0.04^{* *}\end{array}$ & $\begin{array}{l}2 \cdot 30 \\
2 \cdot 17\end{array}$ & $\begin{array}{l}0.04 \\
0.05^{*}\end{array}$ \\
\hline $\begin{array}{l}30 \mathrm{C} \\
30 \mathrm{CB}\end{array}$ & $\begin{array}{l}4 \\
3\end{array}$ & $\begin{array}{l}29 \cdot 6 \\
35 \cdot 3\end{array}$ & $\begin{array}{l}0.9 \\
1.3\end{array}$ & $\begin{array}{l}0.851 \\
0.861\end{array}$ & $\begin{array}{l}0.025 \\
0.012\end{array}$ & $\begin{array}{l}0.835 \\
0 \cdot 868\end{array}$ & $\begin{array}{l}0.008 \\
0.016\end{array}$ & $\begin{array}{l}1 \cdot 58 \\
1 \cdot 16\end{array}$ & $\begin{array}{l}0.08 \\
0.03 * *\end{array}$ & $\begin{array}{l}2 \cdot 31 \\
2 \cdot 19\end{array}$ & $\begin{array}{l}0.06 \\
0.04 *\end{array}$ \\
\hline $\begin{array}{l}30 \mathrm{P} \\
30 \mathrm{~PB}\end{array}$ & $\begin{array}{l}4 \\
4\end{array}$ & $\begin{array}{l}28 \cdot 5 \\
33 \cdot 8\end{array}$ & $\begin{array}{l}0.3 \\
0.6\end{array}$ & $\begin{array}{l}0.852 \\
0.864\end{array}$ & $\begin{array}{l}0.016 \\
0.010\end{array}$ & $\begin{array}{l}0.904 \\
0.880\end{array}$ & $\begin{array}{l}0.008 \\
0.007\end{array}$ & $\begin{array}{l}1.25 \\
1.21\end{array}$ & $\begin{array}{l}0.05 \\
0.02\end{array}$ & $\begin{array}{l}4 \cdot 35 \\
2 \cdot 15\end{array}$ & $\begin{array}{l}0.10 \\
0.08^{* *}\end{array}$ \\
\hline
\end{tabular}

$\mathrm{W}^{0} \cdot 75$, body-weight ${ }^{0 \cdot 75}$ (metabolic body-weight).

Statistical significance of differences between supplemented and basal groups: $P<0.05, * * P<0.01$.

$\dagger$ For details of diets and feeding schedule, see above. 
animals reached $25 \mathrm{~kg}$ body-weight, bladder catheters were introduced and collections of urine and faeces were begun. At this time the amount of diet that was offered was adjusted to give the desired intakes of energy and protein for an animal weighing $28 \mathrm{~kg}$.

The collections of excreta were continued for $7 \mathrm{~d}$ and during the last $4 \mathrm{~d}$ of this period $24 \mathrm{~h}$ measurements of gaseous exchange were carried out as described by Reeds et al. (1980). During the last day of the balance period an aqueous solution of $\mathrm{L}-\left[1-{ }^{14} \mathrm{C}\right]$ leucine (Radiochemical Centre, Amersham, Bucks) with sodium chloride $(9 \mathrm{~g} / 1)$ was infused for $6 \mathrm{~h}$ at a constant rate $(13.5 \mu \mathrm{Ci} / \mathrm{h}, 3.37 \mathrm{ml} / \mathrm{h})$, a continuous record of the excretion of ${ }^{14} \mathrm{C}$ in expired air being obtained during the infusion. During the last $1.5 \mathrm{~h}$ of the infusion, when the specific radioactivity of the expired ${ }^{14} \mathrm{CO}_{2}$ was constant, four blood samples $(10 \mathrm{ml})$ were taken at 20 minute intervals. To these blood samples $1.25 \mu \mathrm{mol} \mathrm{L}$-norleucine was added and the samples were stored at $-20^{\circ}$ until analysed for $\left[{ }^{14} \mathrm{C}\right]$ leucine. Body protein synthesis was calculated as the difference between the apparent irreversible loss of blood leucine and the rate of levicine catabolism (Reeds et al. 1980; Garlick et al. 1980) on the assumption that the relationship between the specific radioactivity of leucine in the blood and in the pool of leucine which acts as the precursor for protein synthesis was unaffected by the dietary supplements.

At the end of this period the bladder catheters were removed and the animals were offered the basal diet once hourly at a daily rate of $90 \mathrm{~g} / \mathrm{kg} \mathrm{W}^{0.75}$ until they weighed $32 \mathrm{~kg}$, when a second series of measurements of $\mathrm{N}$ balance $(7 \mathrm{~d})$, energy balance $(4 \mathrm{~d})$ and body protein turnover were made. During this period the animals were offered the basal diet at a rate appropriate to an animal weighing $34 \mathrm{~kg}$.

The analytical measurements and calculations were made as described by Reeds $\mathrm{et}$ al. (1980), heat production being calculated with the equation given by Brouwer (1965). The statistical significance of differences between means was assessed by Student's $t$ test for paired or non-paired groups as appropriate.

\section{RESULTS}

The apparent digestibilities of energy and $\mathrm{N}$ and the intakes of ME and ADN are shown in Table 1. With the exception of the high apparent digestibility of $\mathbf{N}$ in the high-protein diet there were no differences between diets in the digestibility of energy or of $\mathbf{N}$. The amounts of each diet offered to the animals had been calculated to give equal protein intakes from the basal, carbohydrate and fat-supplemented diets and equal ME intakes from the protein-supplemented and basal diets. In the event there were small, but statistically significant, differences between the intakes of $\mathrm{ADN} / \mathrm{unit}^{\mathrm{W}^{0.75}}$ between groups $30 \mathrm{C}$ and $30 \mathrm{CB}$ and between groups $30 \mathrm{~F}$ and $30 \mathrm{FB}$.

$\mathrm{N}$ retention was higher, both in absolute terms and per $\mathrm{kg} \mathrm{W}^{0.75}$, during all the periods of supplemented feeding (Table 2). The rate of energy retention was also increased in groups $30 \mathrm{C}$ and $30 \mathrm{~F}$ but not in the animals receiving the protein-supplemented diet. Although not reaching statistical significance the mean rate of fat deposition calculated from the difference between energy and $\mathrm{N}$ retention was lower in group 30P than in group 30PB. Increased intakes of carbohydrate and fat were associated with similar increases in daily heat production (Table 2) but the heat production of the animals that were given the highprotein diet increased by less than half. $(30 \mathrm{~F}-30 \mathrm{FB}=129 ; 30 \mathrm{C}-30 \mathrm{CB}=104$; $30 \mathrm{P}-30 \mathrm{~PB}=43 \mathrm{~kJ} / \mathrm{kg} \mathrm{W}^{0.75}$ per d).

The estimates of body protein turnover and leucine catabolism are shown in Table 3. Leucine catabolism (expressed as the proportion of the dose of ${ }^{14} \mathrm{C}$ excreted as $\mathrm{CO}_{2}$ ) was decreased by $58 \%$ in groups $30 \mathrm{C}$ and $30 \mathrm{~F}$ and increased by $73 \%$ in group $30 \mathrm{P}$. In groups $30 \mathrm{C}$ and $30 \mathrm{~F}$ body protein synthesis, expressed per $\mathrm{kg} \mathrm{W}^{0.75}$, was significantly greater than the values for groups 30CB and 30FB but the differences were small. There was a much 
Table 2. The daily heat production, retention of energy and nitrogen, together with an estimate of the daily retention of fat $\dagger$, of twelve female pigs offered basal diets $\ddagger$ supplemented with fat (group 30F), carbohydrate (group 30C) or protein (group 30P) for $14 \mathrm{~d}$ and of the same pigs subsequently offered the basal diet for $14 d$ (groups 30FB, 30CB and 30PB)

(Mean values \pm 1 SEM)

\begin{tabular}{|c|c|c|c|c|c|c|c|c|c|c|c|c|c|}
\hline \multirow{3}{*}{$\begin{array}{l}\text { Dietary } \\
\text { group }\end{array}$} & \multirow[b]{3}{*}{$n$} & \multirow{2}{*}{\multicolumn{2}{|c|}{$\begin{array}{l}\text { Daily heat } \\
\text { production }\end{array}$}} & \multicolumn{4}{|c|}{ Daily energy retention } & \multicolumn{4}{|c|}{ Daily $\mathrm{N}$ retention } & \multirow{2}{*}{\multicolumn{2}{|c|}{$\begin{array}{c}\text { Daily fat } \\
\text { retention } \\
\text { (g fat } / \mathrm{kg} \mathrm{W}^{0 \cdot 7 s} \text { ) }\end{array}$}} \\
\hline & & & & \multicolumn{2}{|c|}{$\mathbf{M J}$} & \multicolumn{2}{|c|}{$\mathbf{k J} / \mathbf{k g} \mathbf{W}^{\mathbf{0} \cdot \mathbf{b}}$} & \multicolumn{2}{|c|}{$\mathbf{g} \mathbf{N}$} & \multicolumn{2}{|c|}{ g N/kg W0.7s } & & \\
\hline & & Mean & $\mathbf{S E}$ & Mean & SE & Mean & $\mathbf{S E}$ & Mean & SE & Mean & SE & Mean & SE \\
\hline $\begin{array}{l}30 \mathrm{~F} \\
30 \mathrm{FB}\end{array}$ & $\begin{array}{l}4 \\
4\end{array}$ & $\begin{array}{l}856 \\
727\end{array}$ & $\begin{array}{l}25 \\
10^{* * 4}\end{array}$ & $\begin{array}{r}11.8 \\
6.9\end{array}$ & $\begin{array}{l}0.6 \\
0.8^{* *}\end{array}$ & $\begin{array}{l}896 \\
450\end{array}$ & $\begin{array}{l}42 \\
42 * *\end{array}$ & $\begin{array}{l}20.8 \\
13.6\end{array}$ & $\begin{array}{l}0.9 \\
0.7 * *\end{array}$ & $\begin{array}{l}1.60 \\
0.91\end{array}$ & $\begin{array}{l}0.08 \\
0.04^{* *}\end{array}$ & $\begin{array}{r}16.6 \\
7.9\end{array}$ & $\begin{array}{l}0.8 \\
1.0\end{array}$ \\
\hline $\begin{array}{l}30 \mathrm{C} \\
30 \mathrm{CB}\end{array}$ & $\begin{array}{l}4 \\
3\end{array}$ & $\begin{array}{l}876 \\
772\end{array}$ & $\begin{array}{l}20 \\
8 * * \S\end{array}$ & $\begin{array}{l}9 \cdot 2 \\
5 \cdot 3\end{array}$ & $\begin{array}{l}1.2 \\
0.8^{*}\end{array}$ & $\begin{array}{l}746 \\
387\end{array}$ & $\begin{array}{l}57 \\
37^{*}\end{array}$ & $\begin{array}{l}18 \cdot 2 \\
14 \cdot 1\end{array}$ & $\begin{array}{l}1.2^{*} \\
1.0\end{array}$ & $\begin{array}{l}1.41 \\
0.92\end{array}$ & $\begin{array}{l}0.11 \\
0.03^{*}\end{array}$ & $\begin{array}{r}13.5 \\
6.3\end{array}$ & $\begin{array}{l}2.2 \\
0.8 * \xi\end{array}$ \\
\hline $\begin{array}{l}\text { 30P } \\
30 \mathrm{~PB}\end{array}$ & $\begin{array}{l}4 \\
4\end{array}$ & $\begin{array}{l}785 \\
742\end{array}$ & $\begin{array}{l}15 \\
16^{*}\end{array}$ & $\begin{array}{l}5.7 \\
6.6\end{array}$ & $\begin{array}{l}0.8 \\
0.3\end{array}$ & $\begin{array}{l}466 \\
471\end{array}$ & $\begin{array}{l}58 \\
16\end{array}$ & $\begin{array}{l}16.6 \\
13.2\end{array}$ & $\begin{array}{l}0.8 \\
0.4^{*}\end{array}$ & $\begin{array}{l}1.36 \\
0.94\end{array}$ & $\begin{array}{l}0.10 \\
0.02^{*}\end{array}$ & $\begin{array}{l}7.0 \\
8.2\end{array}$ & $\begin{array}{l}1.4 \\
0.4\end{array}$ \\
\hline
\end{tabular}

W0-75, body-weight $^{0 \cdot 75}$ (metabolic body-weight).

Statistical significance of differences between supplemented and basal groups (paired $t$ test): $P<0.05$, ** $P<0.01$.

$\dagger$ Calculated on the basis that the retention of $1 \mathrm{~g} \mathrm{~N}$ represents the retention of $148 \mathrm{~kJ}$ energy and $1 \mathrm{~g}$ fat $39.6 \mathrm{~kJ}$ energy.

$\ddagger$ For details for diets, see p. 540 .

$\S$ Paired $t$ test for diet $30 \mathrm{C} v$. diet $30 \mathrm{CB}$, three animals only.

Table 3. Calculated daily rates of total body protein synthesis, protein breakdown and the catabolism of leucine (expressed as the proportion of dose of $\left[\mathrm{I}^{-14} \mathrm{C}\right]$ leucine excreted as $\mathrm{CO}_{2}$ ) in twelve female pigs offered basal diets $\$$ supplemented with fat (group 30F), carbohydrate (group 30C) and protein (group 30P) and in the same pigs subsequently offered the basal diet for $14 d$ (groups 30FB, 30CB and 30PB)

(Mean values $\pm 1 \mathrm{SEM}$ )

\begin{tabular}{|c|c|c|c|c|c|c|c|}
\hline \multirow{2}{*}{$\begin{array}{l}\text { Dietary } \\
\text { group }\end{array}$} & \multirow[b]{2}{*}{$n$} & \multicolumn{2}{|c|}{$\begin{array}{l}\text { Daily protein synthesis } \\
\left(\mathbf{g} \mathbf{N} / \mathbf{k g} \mathbf{W}^{0 \cdot 75}\right)\end{array}$} & \multicolumn{2}{|c|}{$\begin{array}{l}\text { Daily protein breakdown } \\
\left(\mathrm{g} N / \mathrm{kg} \mathrm{W}^{0 \cdot 75}\right)\end{array}$} & \multicolumn{2}{|c|}{$\begin{array}{l}\text { Leucine catabolism } \\
\text { (proportion of dose } \\
\text { excreted as } \mathrm{CO}_{2} \text { ) }\end{array}$} \\
\hline & & Mean & SE & Mean & SE & Mean & SE \\
\hline $\begin{array}{l}\text { 30F } \\
\text { 30FB }\end{array}$ & $\begin{array}{l}4 \\
4\end{array}$ & $\begin{array}{l}6.01 \\
5 \cdot 58\end{array}$ & $\begin{array}{l}0.19 \\
0 \cdot 17^{*}\end{array}$ & $\begin{array}{l}4 \cdot 14 \\
4 \cdot 60\end{array}$ & $\begin{array}{l}0.18 \\
0.21\end{array}$ & $\begin{array}{l}0.088 \\
0.149\end{array}$ & $\begin{array}{l}0.004 \\
0.006^{* * *}\end{array}$ \\
\hline $\begin{array}{l}30 \mathrm{C} \\
30 \mathrm{CB}\end{array}$ & $\begin{array}{l}4 \\
3\end{array}$ & $\begin{array}{l}6 \cdot 12 \\
5 \cdot 36\end{array}$ & $\begin{array}{l}0 \cdot 16 \\
0 \cdot 10 * \S\end{array}$ & $\begin{array}{l}4 \cdot 39 \\
4 \cdot 42\end{array}$ & $\begin{array}{l}0.14 \\
0.17\end{array}$ & $\begin{array}{l}0.086 \\
0.161\end{array}$ & $\begin{array}{l}0.008 \\
0.004^{* * *} \S\end{array}$ \\
\hline $\begin{array}{l}30 \mathrm{P} \\
30 \mathrm{~PB}\end{array}$ & $\begin{array}{l}4 \\
4\end{array}$ & $\begin{array}{l}7 \cdot 40 \\
5 \cdot 46\end{array}$ & $\begin{array}{l}0.16 \dagger \\
0.12^{* *}\end{array}$ & $\begin{array}{l}5.65 \\
4.43\end{array}$ & $\begin{array}{l}0.22 \dagger \\
0.20^{* *}\end{array}$ & $\begin{array}{l}0.259 \\
0.154\end{array}$ & $\begin{array}{l}0.012 \dagger \\
0.008^{* * *}\end{array}$ \\
\hline
\end{tabular}

W0.75 $^{0}$ body-weight ${ }^{0-75}$ (metabolic body-weight).

Statistical significance of differences between supplemented and basal groups (paired $t$ test): $* P<\cdot 50$; ** $P<0.01$; *** $P<0.001$.

+ Statistical significance of difference from values of dietary groups $30 \mathrm{C}$ and $30 \mathrm{~F}$ (unpaired $t$ test): $P<0.01$.

$\ddagger$ For details of diets, see p. 540 .

$\$$ Paired $t$ test for three animals only. 
greater increase in protein synthesis in the animals receiving the high-protein diet. Protein breakdown, calculated as the difference between the apparent flux of amino acid $\mathbf{N}$ and $\mathbf{N}$ intake, was decreased by $10 \%$ in group $30 \mathrm{~F}$, unchanged in group $30 \mathrm{C}$ and increased by some $30 \%$ in group $30 \mathrm{P}$.

\section{DISCUSSION}

\section{Dietary energy, protein and protein turnover}

In the present experiments, supplementation of the diet with either carbohydrate or fat increased daily $\mathrm{N}$ retention by $1.18 \mathrm{~g} \mathrm{~N}$ for each $\mathrm{MJ}$ increase in daily ME intake $(1.21 \mathrm{~g} \mathrm{~N} / \mathrm{MJ}$ with fat and $1.14 \mathrm{~g} \mathrm{~N} / \mathrm{MJ}$ with carbohydrate). These estimates of the protein-sparing effects of dietary NPE are similar to those calculated for growing rats by Munro (1964) from the results of Forbes et al. (1939). In pigs, Fuller \& Crofts (1977) obtained somewhat lower values than the present estimates, but their measurements were made in castrated male animals in which the rate of $\mathbf{N}$ retention at any given level of protein and energy intake was lower than that obtained in our experiment.

An increase in the protein intake of the animals was also associated with an increased rate of $\mathbf{N}$ retention. The measurements of protein synthesis described in the present paper were made to ascertain whether these increments in $\mathbf{N}$ retention, brought about by different changes in the diet, shared a common mechanism. The estimates of protein synthesis made from the specific radioacitivity of free leucine in the blood suggest that they do not.

Estimates derived in this way are based on the assumption, pointed out above, that the specific radioactivity (SR) of leucine incorporated into protein is the same as that of leucine in the blood. It is not yet established that this is so. Golden \& Waterlow (1977) have pointed out that when the fraction of the flux of the tracer amino acid that is catabolized is known, then on the assumption (common to all methods of calculation of total body protein synthesis from a single amino acid) that the metabolism of the tracer is representative of the metabolism of all free amino acids, the flux of amino acid $\mathbf{N}$ can be calculated from the expression:

$$
\text { Flux }=\frac{\text { rate of nitrogen excretion in the urine }}{\text { fraction of tracer catabolized }} .
$$

This approach involves no assumption about the relative SRs of leucine in blood and that used for protein synthesis. Values for body protein synthesis (g N/kg $\mathbf{W}^{0.75}$ per d) calculated in this way were $7 \cdot 25,9 \cdot 56,8 \cdot 55$ and 6.84 for groups $30 \mathrm{~F}, 30 \mathrm{C}, 30 \mathrm{P}$ and pooled values for the basal diet respectively.

However not all urinary $\mathbf{N}$ is derived directly from the catabolism of amino acids by the animal. Especially with diets based on natural ingredients there may be considerable quantities of non-amino $\mathbf{N}$ derived from the diet which add to urinary $\mathbf{N}$ but not to urea and ammonia, the major end-products of amino acid catabolism. On this ground the excretion of urea and ammonia may be a better reflection of amino acid metabolism than total urinary nitrogen in animals receiving such diets as those used in the present and previous experiments (Reeds et al. 1980). The estimates of body protein synthesis (g N/kg W0.75 per d) based on urinary urea and ammonia are 6.14,6.42, 7.52 and 5.53 for groups $30 \mathrm{~F}, 30 \mathrm{C}, 30 \mathrm{P}$ and pooled basal values compared with the values $6.01,6 \cdot 12$, 7.40 and 5.47 derived from the SR of blood leucine.

It is inevitable that animals grow during an experiment of this nature and it had been planned to minimize the confounding effects of differences in body-weight by making measurements at three body-weights, giving supplements both before and after the animals were given the basal diet. Unfortunately it was found that at the heaviest weight (approximately $40 \mathrm{~kg}$ ) the animals would not maintain a constant intake of supplemented 
diet. Variations in food intake, particularly during the infusion of $\left[{ }^{14} \mathrm{C}\right]$ leucine, invalidate the measurements of body protein synthesis and the necessary extrapolation of these measurements to $24 \mathrm{~h}$ periods (Reeds et al. 1980).

In calculating the amount of each diet to offer to the animals the amount per $\mathrm{kg} \mathrm{W}^{0.75}$ was kept constant and for this reason the majority of the results are expressed in these units. Our conclusions concerning the relative effects of the supplements upon the rates of energy and $\mathrm{N}$ retention are unaffected by their expression either per $\mathrm{kg} \mathrm{W}^{0.75}$ or as absolute quantities. However, when body protein synthesis and breakdown calculated from the labelling of blood leucine are expressed as absolute quantities, supplementation of the diet with NPE apparently has no effect upon the rate of protein synthesis and it follows that expressing the results in this way emphasizes the contribution of reduced protein breakdown to the change in $\mathbf{N}$ retention. Conversely, the higher the exponent of body-weight chosen to calculate the denominator, the greater becomes the apparent significance of changes in protein synthesis. It does however seem reasonable to conclude that the changes in $\mathrm{N}$ retention which were associated with changes in protein intake involved greater increases in the rate of protein synthesis than those associated with changes in the intake of carbohydrate or fat and that the changes in protein metabolism observed in our earlier measurements (Reeds et al. 1980) represented the end result of different and independent responses to alterations of energy and protein intakes.

The results shown in Table 4, where some of our previous (Reeds et al. 1980) and present measurements are compared, suggest that whilst the changes in protein synthesis in response to changing protein intake are the most marked, energy intake can also influence protein synthesis. It can be calculated that in animals of $30 \mathrm{~kg}$ body-weight, body protein synthesis increased by $0.88 \mathrm{~g} \mathrm{~N}$ for each $\mathrm{g}$ increase in ADN at constant energy intake and by $0.93 \mathrm{~g} \mathrm{~N}$ for each MJ increase in ME at constant intake of ADN.

\section{Protein synthesis, protein deposition and heat production}

It has been recognized for some years that many of the estimates of the energy costs of fat and protein deposition are heavily dependant on assumptions regarding the relationship between the maintenance component of heat production and body-weight (Thorbek, 1970; Kielanowski, 1976; Millward et al. 1976; McCracken et al. 1980). It has also been realized that the correlation between the rates of protein and fat deposition is usually so high that

Table 4. Daily body protein synthesis, the catabolism of leucine, and the intakes of metabolizable energy (ME) and apparently digested nitrogen $(A D N)$ in groups $\dagger 30 P, 30 P B$ and $30 \mathrm{C}$ in the present experiments and in dietary group $30 \mathrm{H}$ of Reeds et al. (1980).

(The difference in protein synthesis between the dietary groups can be described by the equation $0.88 x+0.93 y=z 0.02$ residual SD, where $x$ is the change in ADN (g N/d), $y$ the change in intake of ME $(\mathrm{MJ} / \mathrm{d})$ and $z$ is the change in protein synthesis $(\mathrm{g} \mathrm{N} / \mathrm{d})$ )

\begin{tabular}{|c|c|c|c|c|}
\hline \multirow[b]{2}{*}{$\begin{array}{l}\text { Dietary } \\
\text { group }\end{array}$} & \multicolumn{2}{|c|}{ Daily intake } & \multirow{2}{*}{$\begin{array}{l}\text { Daily protein } \\
\text { synthesis } \\
\text { (g N/kg } \mathbf{W}^{0-75} \text { ) }\end{array}$} & \multirow[b]{2}{*}{$\begin{array}{l}\text { Leucine catabolism } \\
(\mu \mathrm{Ci} / \mathrm{mCi} \text { infused })\end{array}$} \\
\hline & $\begin{array}{c}\mathrm{ME} \\
\left(\mathrm{MJ} / \mathrm{kg} \mathrm{W}^{0.73}\right)\end{array}$ & $\begin{array}{c}\text { ADN } \\
\left(\mathrm{g} \mathrm{N} / \mathrm{kg} \mathrm{W}^{0.78}\right)\end{array}$ & & \\
\hline $30 \mathrm{P}$ & 1.25 & 4.35 & $7 \cdot 40$ & 259 \\
\hline 30PB & $1 \cdot 21$ & $2 \cdot 15$ & 5.46 & 154 \\
\hline $30 \mathrm{~F}$ & 1.75 & $2 \cdot 30$ & $6 \cdot 07$ & 87 \\
\hline $30 \mathrm{H}$ & 1.57 & 2.90 & 6.46 & 118 \\
\hline
\end{tabular}

$\dagger$ For details of diets, see p. 540. 
the precise separation of their energy costs is difficult (Pullar \& Webster, 1977). In the present experiments the amounts of carbohydrate, fat and protein that were added to the basal diet were calculated to give equal increments in $\mathbf{N}$ retention with the aim of separating protein and fat deposition. In addition it was hoped that by basing calculations upon the differences between groups of animals of similar body-weights a necessary assumption as to the relationship between body-weight and maintenance heat production could be avoided (Pullar \& Webster, 1977).

The comparison of the results of groups 30C and 30P (Table 2) in which the rates of protein deposition are nearly identical, suggests that the increase in heat production associated with the increase in fat deposition, presumably synthesized from carbohydrate, was $14 \mathrm{KJ} / \mathrm{g}$. This is greater than the value that can be derived from the stoichiometry of triglyceride synthesis from glucose (Blaxter, 1967; Millward et al. 1976) but close to the values estimated in sheep for the efficiency of utilization for fattening of an intra-cardial infusion of glucose (Armstrong et al. 1960).

A similar calculation of the energetic efficiency of protein deposition, using the results of groups 30P and 30PB, suggests a heat increment of $17 \cdot 1 \mathrm{KJ} / \mathrm{g}$ protein deposited but this calculation is less satisfactory owing to the slightly different rates of fat deposition in these two groups. If these differences are taken into account (assuming a heat increment of $14 \mathrm{KJ} / \mathrm{g}$ fat deposited) the apparent energy cost of protein deposition rises to $23.5 \mathrm{KJ} / \mathrm{g}$ protein deposited.

The suggestion has been made that the apparently high energy cost of protein deposition (expressed as the increase in heat production per unit protein deposited) is due, in part at least, to the energy required for body protein turnover. It has however been demonstrated in both pigs (Reeds et al. 1980) and children (Golden et al. 1977) that a significant proportion of body protein synthesis continues at $\mathrm{N}$ equilibrium. It follows that it is only the additional protein synthesis associated with growth that should be included in the heat increment which is statistically related to protein deposition.

The energy exchanges of the animals that were given the supplements of NPE were dominated by differences in the rate of deposition of body fat and the changes in protein synthesis were small. The calculation of the proportion of heat production associated with protein synthesis is extremely dependant on the accuracy of the estimate of the energy cost of fat deposition, which may not be the same in groups $30 \mathrm{C}$ and $30 \mathrm{~F}$. On the other hand, on all bases of calculation, there was a substantial change in body protein synthesis in the animals that were given the protein supplement and the differences in heat production and protein synthesis between groups $30 \mathrm{P}$ and $30 \mathrm{~PB}$ suggest a heat increment of $3.8 \mathrm{KJ} / \mathrm{g}$ protein synthesized and $5.32 \mathrm{KJ} / \mathrm{g}$ if the energy cost of fat deposition is taken into account. These values are closer to the theoretical energy requirement for protein synthesis (Buttery \& Boorman, 1976; Millward et al. 1976). They imply that, in the animals receiving the protein supplement a high proportion of the energy cost of the additional protein deposition can be ascribed to the additional protein synthesis associated with this treatment.

It is impossible to say whether this last conclusion, based on results obtained under a specific dietary circumstance, is applicable to animals given other diets. The results suggest that the relationship between protein synthesis and protein deposition is not fixed but is influenced by the nature of the diet. Thus if the change in protein deposition were the principle influence upon the energy cost of protein deposition, then the energetic efficiency of protein deposition would be variable. Further examination of the validity of this interpretation of the energy cost of protein deposition must await information on the extent to which other processes, which contribute to the heat production of the animal and which may be linked directly or indirectly to protein synthesis, vary with the nature of the diet. 


\section{REFEREN CES}

Armstrong, D. G.; Blaxter, K. L. \& Graham, N. McC. (1960). Proc. Nutr. Soc. 19, xxxi.

Blaxter, K. L. (1967). The Energy Metabolism of Ruminants, 2nd ed. London: Hutchinson.

Brouwer, E. (1965). Publs Eur. Ass. Anim. Prod. no. 11, p. 441.

Buttery, P. J. \& Boorman, K. N. (1976). In Protein Metabolism and Nutrition p. 197 [D. J. A. Cole, K. N. Boorman,

P. J. Buttery, D. Lewis, R. J. Neale and H. Swan, editors]. London: Butterworths.

Forbes, E. B, Bratzler, J. W., Thacker, E. T. \& Marcy, L. F. (1939). J. Nutr. 18, 57.

Fuller, M. F. \& Crofts, R. M. J. (1977). Br. J. Nutr. 38, 479.

Fuller, M. F., Weekes, T. E. C., Cadenhead, A. \& Bruce, J. B. (1977). Br. J. Nutr. 38, 489.

Garlick, P. J., Clugston, G. A. \& Waterlow, J. C. (1980). Am. J. Physiol. 238, E235.

Golden, M. H. N. \& Waterlow, J. C. (1977). Clin. Sci. mol. Med. 53, 277.

Golden, M. H. N., Waterlow, J. C. \& Picou, D. (1977). Am. J. clin. Nutr. 30, 1345.

Kielanowski, J. (1972). In Festkrift til Knut Breirem, p. 111 [L. S. Spildo, T. Homb and H. Hvidsten, editors]. Oslo: Mariendals Boktrykkeri A. S. Gjøvidk.

Keilanowski, J. (1976). In Protein Metabolism and Nutrition p. 107 [D. J. A. Cole, K. N. Boorman, P. J. Buttery, D. Lewis, R. J. Neale and H. Swan, editors]. London: Butterworths.

McCracken, K. J., Eddie, S. M. \& Stevenson, W. G. (1980). Br. J. Nutr. 43, 305.

Millward, D. J., Garlick, P. J. \& Reeds, P. J. (1976). Proc. Nutr. Soc. 35, 339.

Munro, H. N. (1964). In Mammalian Protein Metabolism, vol. 1, p. 381 [H. N. Munro and J. B. Allison, editors]. New York: Academic Press.

Munro, H. N., Black, J. G. \& Thomson, W. T. (1959). Br. J. Nutr. 13, 475.

Nakano, K., Ando, T. \& Ashida, K. (1973). J. Nutr. 104, 264.

Nakano, K. \& Ashida, K. (1969). J. Nutr. 100, 208.

Nakano, K. \& Ashida, K. (1975). J. Nutr. 105, 906.

Pullar, J. D. \& Webster, A. J. F. (1977). Br. J. Nutr. 38, 1.

Reeds, P. J., Cadenhead, A., Fuller, M. F., Lobley, G. E. \& McDonald, J. D. (1980). Br. J. Nutr. 43, 455.

Thorbek, G. (1970). In Energy Metabolism of Farm Animals p. 129 [A. Schürch and G. Wenk, editors]. Zurich: Julius Druck \& Verlag. 